\title{
Five transition pathways to renewable energy futures-scenarios from a Delphi study on key drivers and policy options
}

\author{
Pasi Rikkonen ${ }^{1 *} \mathbb{D}$, Ville Lauttamäki ${ }^{2}$, Marjukka Parkkinen ${ }^{2}$, Vilja Varho ${ }^{1}$ and Petri Tapio ${ }^{2}$
}

\begin{abstract}
At many levels of society -in regions, corporations, and among citizens-awareness is increasing, and actions towards more sustainable energy are being taken. The key drivers of this transition have been climate change, the scarcity of resources, and environmental consciousness. The speed of change and its impacts on the energy system transition are still unknown. It is therefore important to anticipate probable, preferable, or avoidable future paths that will contribute to the discussion of the direction and conditions of such futures. In this article, five energy scenarios are presented for Finland until 2030. The scenarios are based on a two-round Delphi application, in which energy experts were first interviewed and then a survey phase was conducted. We used cluster analysis to construct the scenarios and arranged the responses to open-ended questions as narratives to deepen the scenarios. Based on the cluster analysis, five clusters were constructed, namely, (1) business as usual, (2) energy saving and decarbonisation, (3) climate-friendly transformation, (4) green growth, and (5) degrowth. These scenarios illustrate how varying sets of drivers of change in society, and a set of energy policy measures, are connected with energy futures. Expert information thus organised can be used to advise policymakers when designing future climate and energy policy.
\end{abstract}

Keywords: Delphi method, Renewable energy, Scenario planning, Transition science

\section{Introduction}

The current and projected climate change requires urgent and consistent action of fossil fuel-based energy systems throughout the world. In the member countries of the European Union, the EU-wide target for the share of renewable energy (RE) sources for 2030 is set to at least $32 \%$ of all final energy consumption [1]. Despite the rhetoric of carbon neutrality and many policies supporting the change, the $\mathrm{EU}$ is lagging significantly behind this goal, with an $18 \%$ share of renewable energy in gross final energy consumption (Fig. 1).

Since the EU member countries contain various volumes of renewable energy in their area, the countries have varying targets for the share of renewable energy

\footnotetext{
*Correspondence: pasi.rikkonen@luke.fi

${ }^{1}$ Natural Resources Institute Finland (Luke), Mikkeli, Finland

Full list of author information is available at the end of the article
}

sources, as well as various ways of achieving the target. It is widely recognised today that transforming the energy system from one that is based on the extensive use of fossil fuels requires changes that go deeper than merely replacing fossil fuels with renewable energy sources [2].

The fossil energy regime is characterised by a somewhat centralised energy production system. Transforming this system towards more decentralised energy production has been raised as a partial solution to increase the share of renewable energy sources in the energy mix [3]. Decentralised energy production allows the use of the renewable energy resources available in the proximity of energy end-users, thus increasing the use of such resources, as well as adding diversity in used renewable energy sources and technologies.

In this article, the focus is on how the shift to a more renewable energy system might take place in Finland. Recent updates on the Finnish national energy policy 


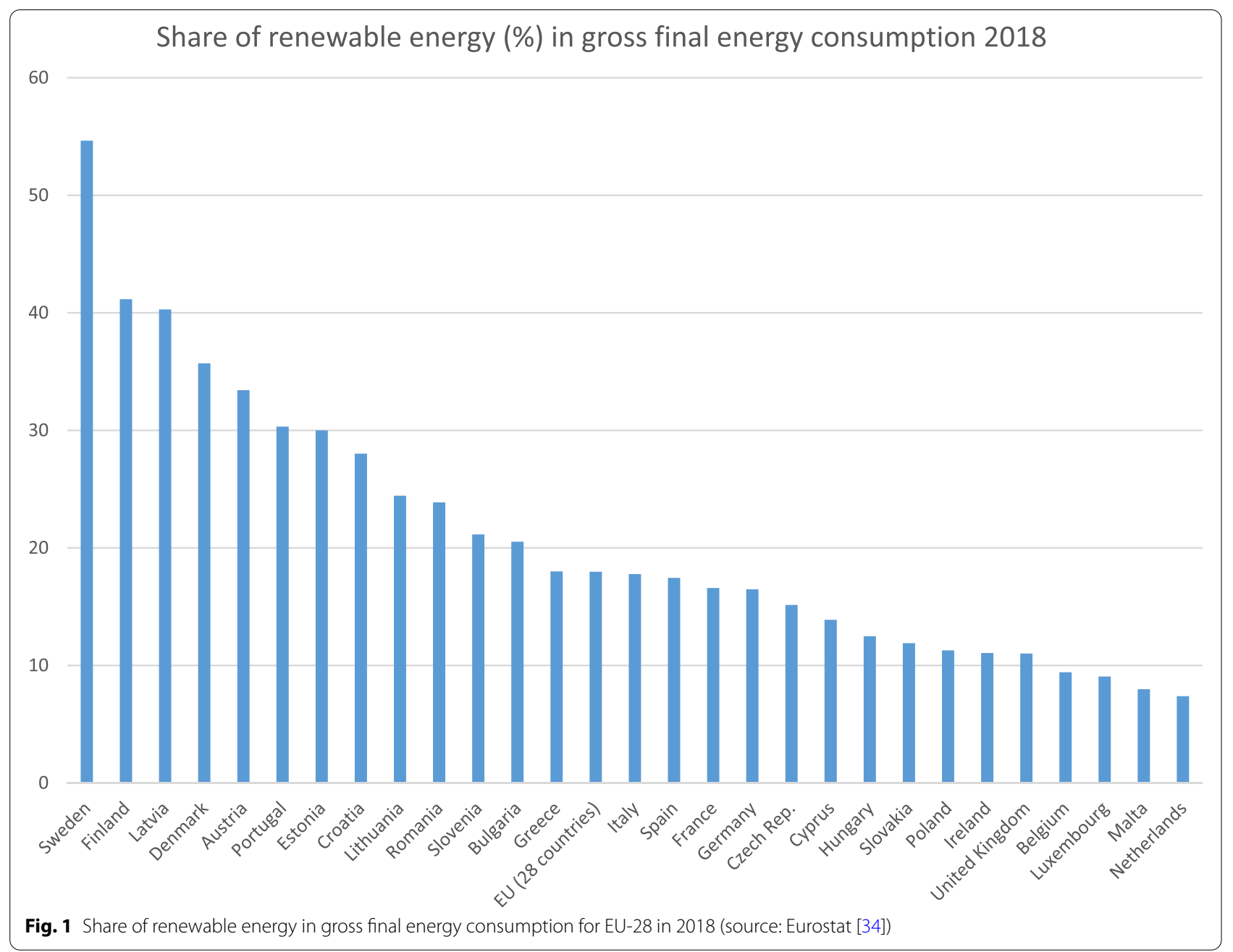

include abandoning the use of coal in energy production and oil in heating by 2030 and achieving the carbon neutrality of the whole society by 2035 [4]. These ambitious targets call for new ways of organising energy provision and increasing the share of renewable energy. As seen in Fig. 1, Finland is among the countries with the highest share of renewable energy (41\%). This owes much to abundant forest resources and the large pulp and paper and sawmill industry. The significant role of wood-based energy sources (wood fuels and black liquor) in the total share of renewable energy sources in Finland in 2018 is displayed in Fig. 2.

An interesting feature of the current Finnish energy system is that a considerable amount of the produced renewable energy (black liquor and a large part of the raw materials for wood fuels) is a by-product of the pulp and paper industry. This makes the current energy system somewhat vulnerable, because a large drop in demand for paper and cardboard might have considerable effects on Finland's ability to produce renewable energy. Another precondition of Finnish renewable energy is that the potential of hydropower is widely considered to be nearly fully exhausted.

In considering these preconditions and energy policy targets, this research focuses on how a transition to a more renewable energy system might take place in Finland by 2030. Based on the views of experts in the energy sector in Finland, this research builds an understanding of how the future of energy provision in Finland is perceived and the role renewable decentralised energy sources might play in various energy futures. Instead of traditional engineering or economic modelling, we focus on expert views of the future. As the future does not exist, and as there is a considerable desire for systemic change, the relationships of parameters in models may also change in the future. By using the Delphi method and cluster analysis, the views of experts are organised in distinctive scenarios. This allows for a 'multi-theoretical' approach in understanding both incremental and radical potential changes in energy system dynamics without 


\section{Shares of renewable energy sources in Finland in 2018}

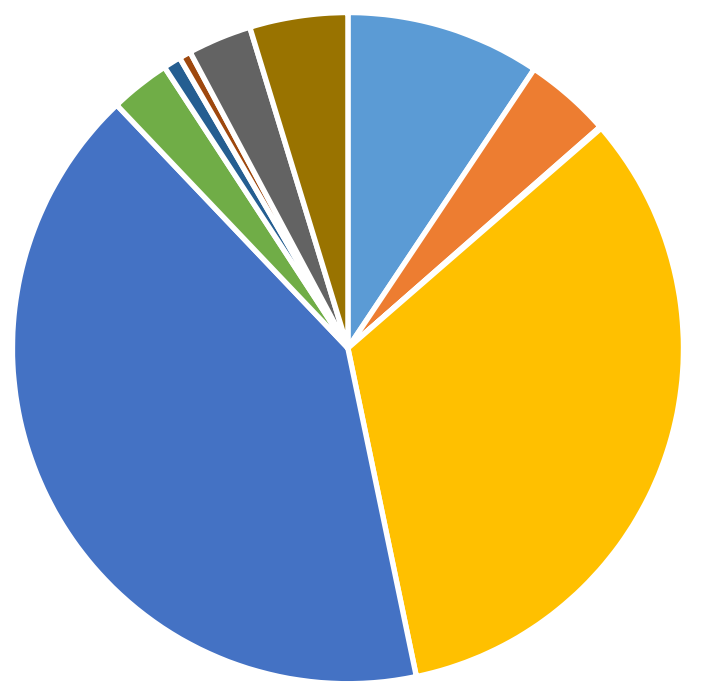

$$
\begin{aligned}
& \text { - Hydropower } \quad \text { Wind power }=\text { Solar energy }=\text { Black liquor } \\
& \text { - Recovered fuels " Other bioenergy - Biogas - Bioliquids }
\end{aligned}
$$

- Wood fuels

- Heat pumps

Fig. 2 Relative shares of renewable energy sources in Finland in 2018 (source: Statistics Finland [35])

losing exactness in describing the transition endpoints $($ see $[5,36])$.

There are several recent examples of using cluster analysis with the Delphi method to build scenarios (e.g. [6-8]). Typically, these include a Delphi process of two or three argumentation rounds that produces expert views concerning the future of a chosen topic or field $[9,10]$. Information produced with Delphi is analysed using cluster analysis to produce distinctive scenarios, and the analysis is usually performed based on experts' views on the impact, probability, and sometimes desirability [6] of issues affecting the future of the chosen topic.

In this research, cluster analysis is used to build scenarios that illustrate how varying sets of drivers of change in society and a set of energy policy measures are connected with energy futures. Expert information thus organised can be used to advise policymakers when designing climate and energy policy.

The research questions this paper addresses are as follows:

- How do experts see the alternative paths of renewable energy use and its share in total consumption in Finland until 2030?

- What kind of future developments of key transition drivers in societal change can be identified among experts' views of the future?
- What role do energy policy and its targeted measures play in this transition?

\section{Material and methods \\ Data gathering}

The material in this study consists of quantitative and qualitative data, which was gathered through a tworound Delphi application, combined with forerunner interviews and an expert survey. This approach is considered very suitable for research in which pragmatism is sought [11]. The first round consisted of in-depth expert interviews, followed by a structured questionnaire round, including both quantitative and qualitative questions. This combination provided added value that could not have been attained with surveys or interviews, or a quantitative or qualitative approach alone.

We started the interviews with representatives from the Finnish small-scale renewable energy system. The interviewees represented three technologies in different development phases in Finland, namely, (1) groundsource heat pumps (expansion phase), (2) biogas (early phase), and (3) wood chips (institutionalised). Altogether, 67 interviews were carried out between 2015 and 2017 . The interviews were audiotaped and transcribed. The interviews in each case technology were conducted as separate processes and then analysed separately through 
qualitative content analysis. Some results from the interviews have been reported in [12-14], and [15].

For the second Delphi round, an online expert questionnaire was constructed, partly based on the most important themes that emerged from the interviews. The invitation to respond to the online questionnaire (uploaded to the Webropol survey tool) was sent by email to approximately 100 recipients in November 2018. The mailing list included the interviewees from the first round with additional technology advisers, researchers, and politicians in the RE field. The goal was to reach a well-balanced expertise coverage of the different fields of RE.

Several reminders were sent to the respondents to ensure a sufficient response rate. The questionnaire was closed in January 2019, gathering a total of 21 responses. The respondents are characterised in Fig. 3 . The aim of an expert survey was not to produce a statistically representative sample, but rather to reach a coverage of experts through theoretical sampling. The respondents' expertise covers different energy sources well, and the experts come evenly from rural and urban areas. This is significant, because many of the renewable energy sources are located in rural areas, but the majority of Finnish people live in towns or cities. As a Delphi panel of a technologically oriented topic, this panel was 'typically biassed', because the majority were middle-aged male experts.

Originally, the questionnaire covered three sections. The emphasis of each section was on quantitative data. The respondents were allowed to provide qualitative arguments for each of the quantitative responses. This paper focuses on sections 1 and 2.

The first part of the questionnaire addressed the experts' views concerning the probable and preferable development of renewable energy sources, and the share of renewable energy of the total energy consumption in Finland until 2030. The preferable future was defined as the most sustainable possible development in technological, economic, political, and societal terms. Answers were given as $\mathrm{GWh} / \mathrm{a}$ for energy production variables and as a percentage in the case of the share of renewable energy of the total energy consumption in Finland. Responses were sought for the years 2020, 2025, and 2030 (see Table 1 and Figs. 4, 5, 6, 7, and 8). Background data was provided regarding the actual development of each variable for $2000-2016$ or $2000-2017$, depending on the latest available information. The data for the time series was received from Statistics Finland [16].

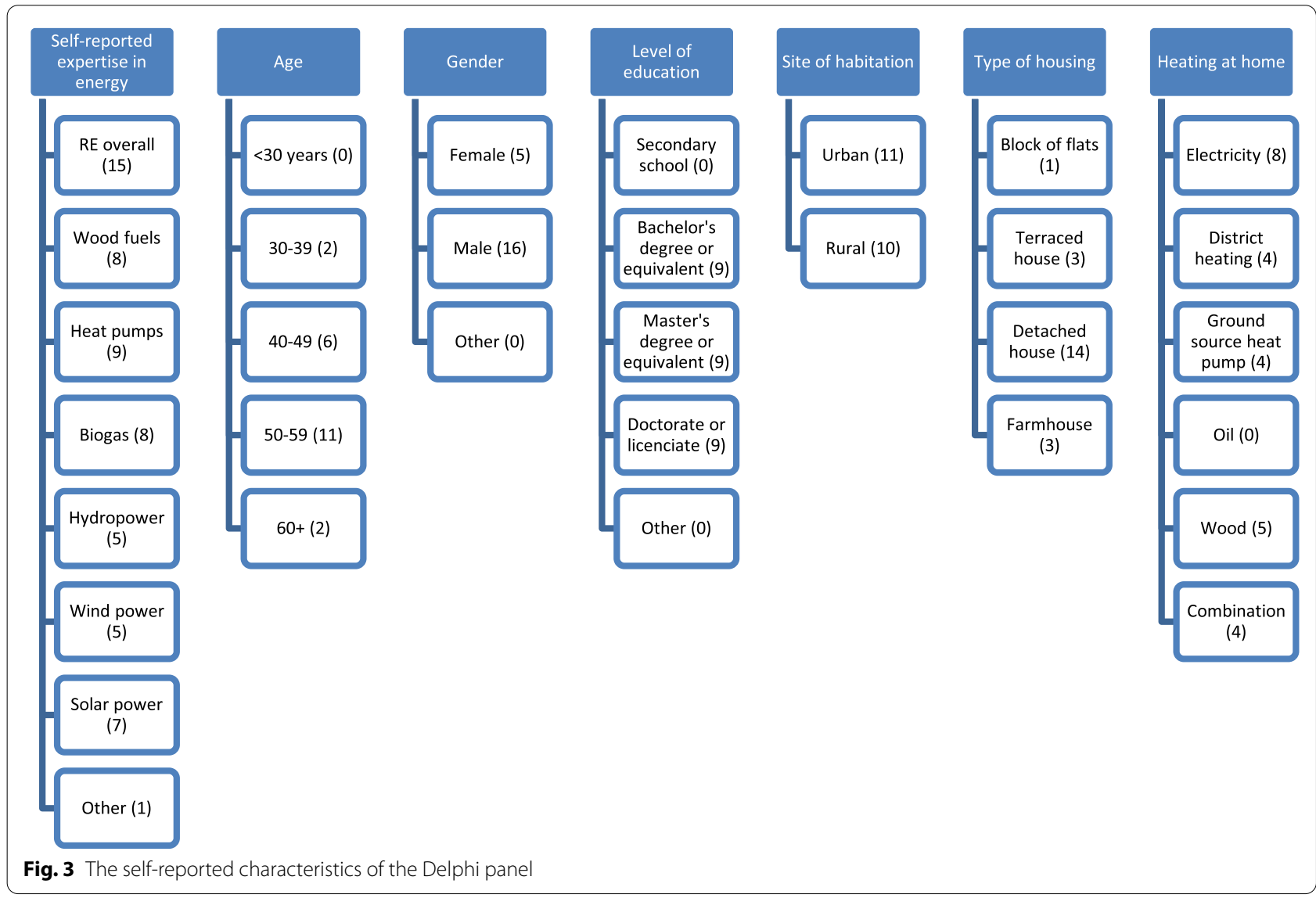




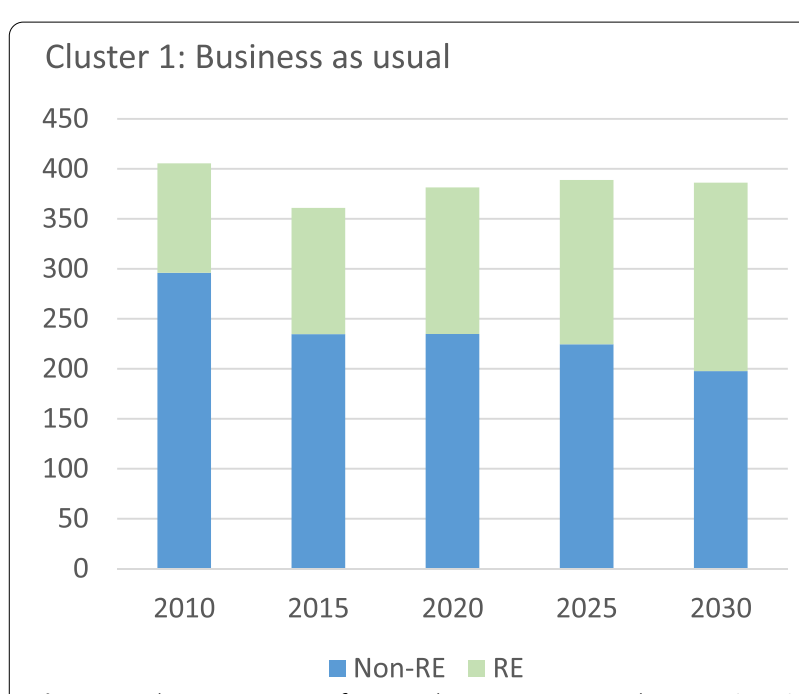

Fig. 4 Total consumption of energy between 2010 and 2030 in 'BAU' scenario (N.B. the total consumption was 378 TWh in 2019; years 2010 and 2015 added [35])

The second part of the questionnaire gathered views about (1) the changes in the operating environment of energy technologies and (2) RE policy measures. This section's questions are listed with the results in Tables 2 and 3. The range of responses used a 7-step Likert scale $(-3=$ disagree completely, $-2=$ disagree, $-1=$ disagree somewhat, $0=$ not agree, not disagree, $1=$ agree somewhat, $2=$ agree, $3=$ agree completely). It was also possible to answer 'I don't know' or not to answer at all.

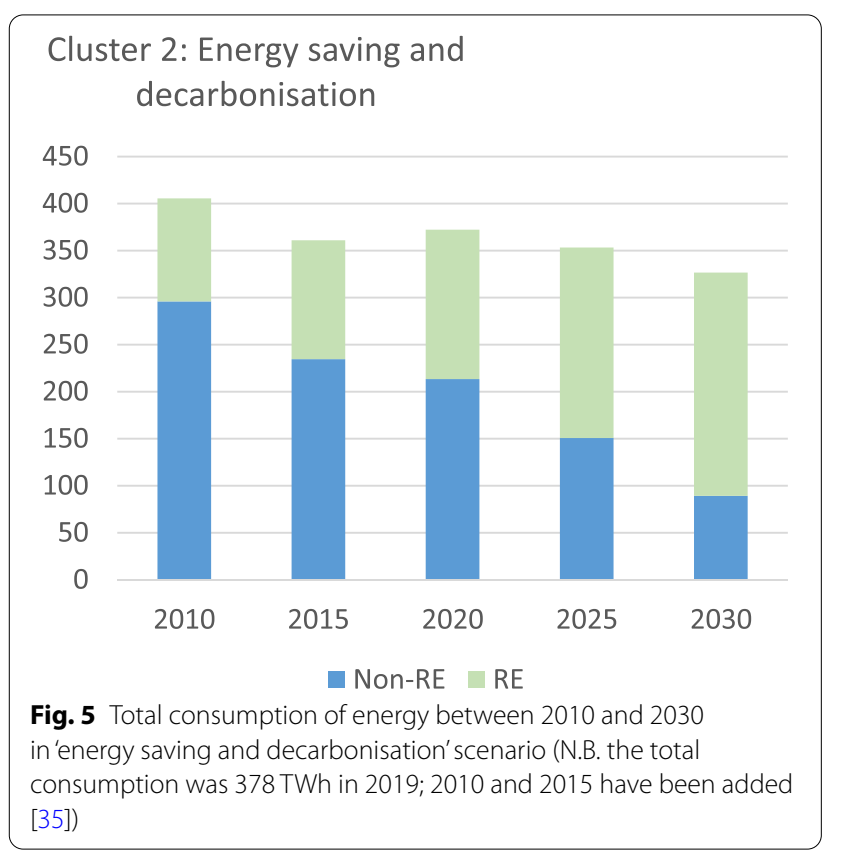

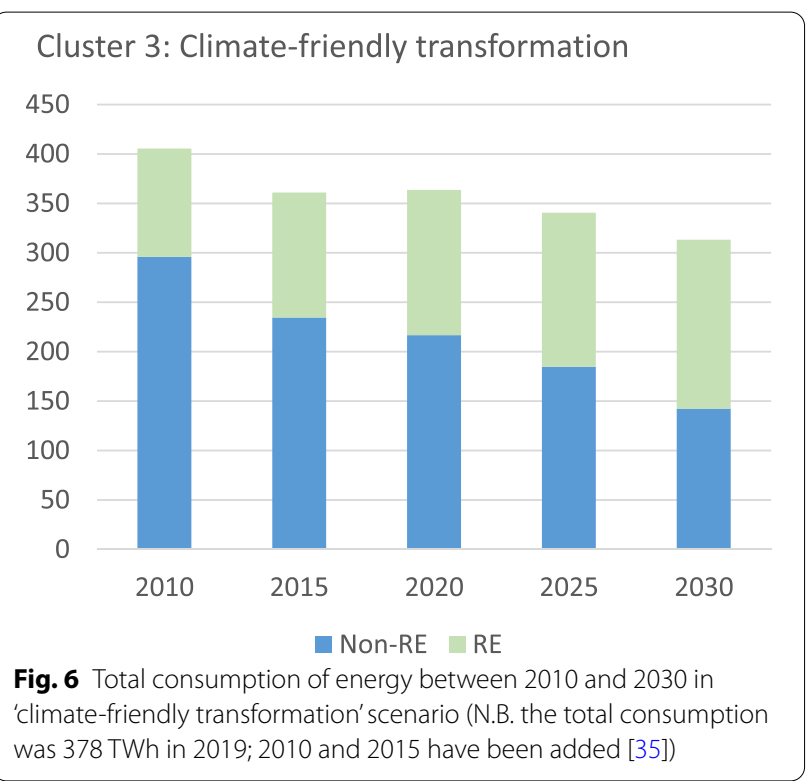

The respondents were asked to evaluate statements from the present day until 2030. Many of the statements were formulated based on the first round interviews. In addition, questions were formed based on the results of a survey in which 17-75-year-old Internet users living in Finland $(n=1012)$ were asked how important they considered different drivers to be in reducing the environmental and climate impacts of energy production in Finland [17]. The responses of that survey were analysed using factor analysis, which grouped items based on shared variance. Sixteen of the items loaded strongest to their respective factors were reformulated as statements and included in the Delphi questionnaire.

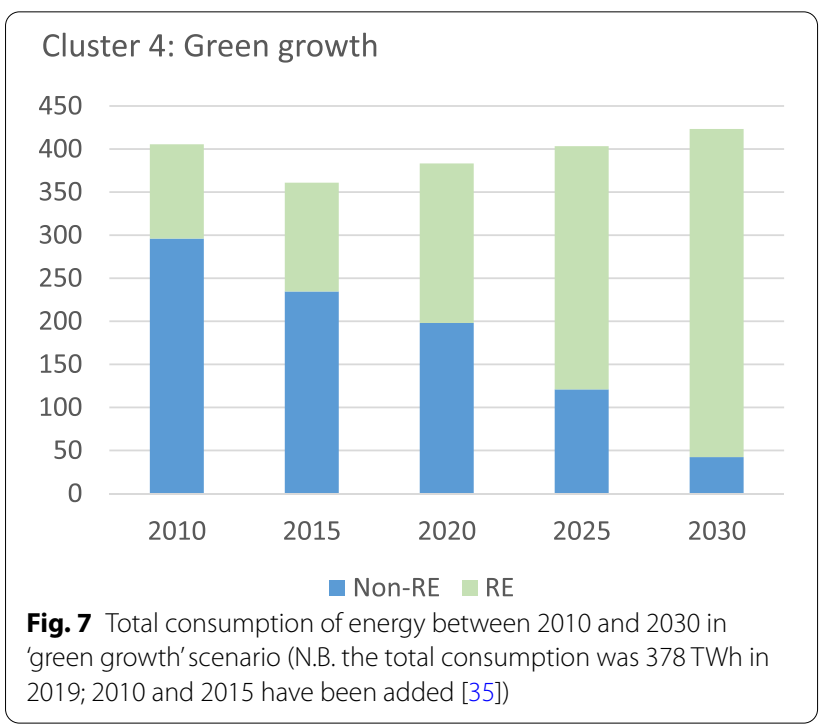




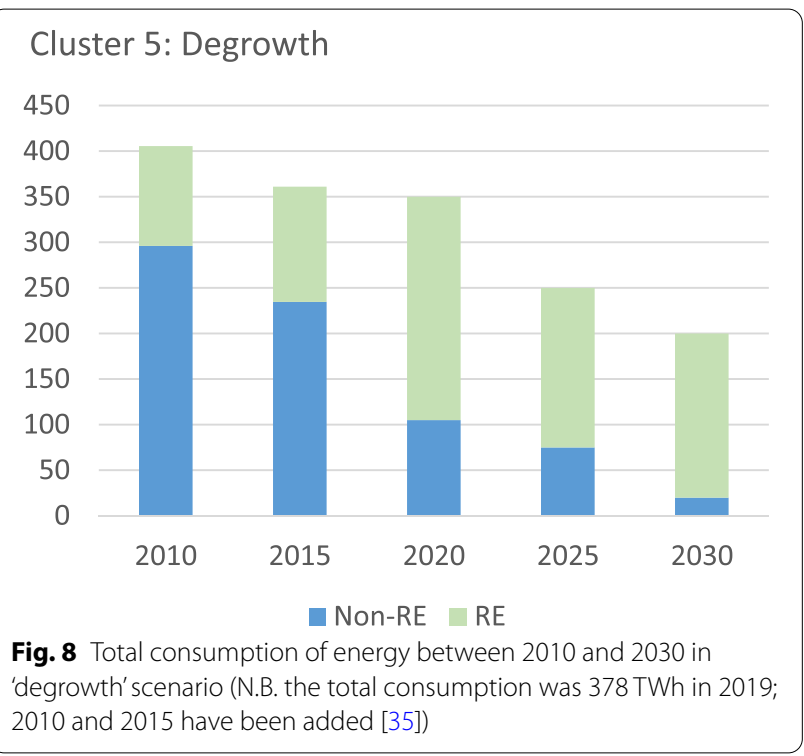

\section{Data analysis methods}

To construct scenarios, the quantitative data from the second Delphi round were grouped using hierarchical cluster analysis in the SPSS software.

In questionnaire section 1 , the respondent gave his/her opinion on a given time series in which the historical data was given, and experts gave their future view as three values for the years 2020, 2025, and 2030. Since the variable scales differed greatly, the answers in the first section were standardised for cluster analysis. The maximum value for 2030 regarding total energy consumption estimates was given the value of 100 , and the other responses were calculated linearly downwards from the maximum. The maximum response for the share of renewable energy was in fact 100, so standardisation was unnecessary in this case. An equal weight for all six variables was used. For illustration, the absolute volumes of renewable and non-renewable energy production were calculated.

The data from the second section of the questionnaire was used directly without data standardisation or weighting. The two datasets in the second section of the questionnaire were analysed separately in two SPSS runs, namely, (1) the data of changes in the operating environment of energy technologies and (2) the data of policy measures.

Cluster analysis is an exploratory method [18]. It has been used in futures studies, especially in the construction of scenarios through the Delphi technique in agricultural and forestry sectors, energy sector, climate and energy policy foresight, traffic sector, and health sector $[9,10,19-21]$. It groups all responses into a smaller number of different clusters, simplifying the variance within the data. Some 3-7 alternative scenarios have often been considered reasonable (e.g. [21]). Hence, several runs were conducted to test how the data reacted to different clustering algorithms, and which number of chosen clusters provided relevant interpretations. After the iterative testing, the cluster run of five clusters was decided to form the basis of five scenarios in all sections. The cluster centres were calculated as the arithmetic means of each variable within a cluster. In the final statistical runs, we used the furthest neighbour algorithm with the Euclidean distance measure in each of the three separate cluster analyses. The final runs resulted in a reasonably balanced set of clusters that made sense in relation to each other.

Each of the sections in the survey also included openended questions. The responses were used in scenario narratives to deepen the content and contrast of each scenario. The categorisation of the open-ended responses did not automatically follow the clusters. Instead, we sought the most illustrative arguments to enrich each cluster-based scenario. This was done in accordance with the scenario planning literature $[22,23]$.

\section{Results}

\section{Clusters in numbers}

Based on the cluster analysis, five clusters were constructed, namely, (1) business as usual, (2) energy saving and decarbonisation, (3) climate-friendly transformation, (4) green growth, and (5) degrowth. First, the calculated cluster centres in each of the survey's three sections are presented (Tables 1, 2, and 3). The scenario narratives are then described to illustrate the alternative future development in each scenario.

\section{Business as usual}

The business as usual scenario represents the path that follows the current development of increasing the share of renewable energy. Despite the steady increase in environmentally friendly actors, systemic change and decoupling from unsustainable path dependencies and growth-oriented thinking have been slow in this scenario. Globally, the climate and energy policy is facing a headwind; climate actions are suffering, while the focus is on accelerating economic growth. According to the established mindset, Finland is doing enough as it is, and further improvement is seen as unnecessary. Decisionmaking processes continue to be rigid and overly bureaucratic, and investment is inadequate. Citizens have little power to influence the direction of energy policies, which further slows down the transition.

The total consumption of energy has remained quite steady during the 2020s in Finland, despite a minor increase caused by rising living standards and the 
Table 1 The cluster centres in each scenario regarding energy consumption time series

\begin{tabular}{|c|c|c|c|c|c|}
\hline Variable in 2030 & 1. Business as usual & $\begin{array}{l}\text { 2. Energy saving and } \\
\text { decarbonisation }\end{array}$ & $\begin{array}{l}\text { 3. Climate-friendly } \\
\text { transformation }\end{array}$ & 4. Green growth & 5. Degrowth \\
\hline \multicolumn{6}{|c|}{ Total energy consumption } \\
\hline Cluster centre & 386 TWh & 327 TWh & 313 TWh & 423 TWh & $200 \mathrm{TWh}$ \\
\hline $\begin{array}{l}\text { Within cluster } \\
\text { standard deviation (\% } \\
\text { of mean) }\end{array}$ & 4.1 & 6.3 & 9.2 & 4.9 & N.A. ${ }^{a}$ \\
\hline \multicolumn{6}{|c|}{ Share of renewable energy } \\
\hline Cluster centre & $49 \%$ & $73 \%$ & $55 \%$ & $90 \%$ & $90 \%$ \\
\hline $\begin{array}{l}\text { Within cluster } \\
\text { standard deviation (\% } \\
\text { of mean) }\end{array}$ & 11.7 & 7.2 & 12.1 & 9.1 & N.A. ${ }^{\text {a }}$ \\
\hline
\end{tabular}

${ }^{\mathrm{a}}$ Degrowth scenario cluster contains only one response

sparsely populated country's ageing infrastructure and transport. The share of renewable energy has increased as 2030 approaches, but the rate has been quite modest, despite the goals that have been set. The support policy for renewable energy generation will remain at the present level, and no new measures will have been introduced in the 2020s. The available measures will include investment aid to advance the use of renewable energy technologies, and the applied Feed-in-Tariff system for wind, biogas, and wood-based fuel power. Because of these, the profitability of adopting new RE small-scale technologies is increasing, and modest growth is based on corporations' investments and root-level citizen actions. The share of renewable energy will be dominated

Table 2 The cluster centres (mean value) in each scenario regarding the general operating environment (those in bold ones are the ones that stand out between the clusters; scale from -3 to 3 )

\begin{tabular}{|c|c|c|c|c|c|}
\hline & 1. Business as usual & $\begin{array}{l}\text { 2. Energy } \\
\text { saving and } \\
\text { decarbonisation }\end{array}$ & $\begin{array}{l}\text { 3. Climate- } \\
\text { friendly } \\
\text { transformation }\end{array}$ & 4. Green growth & 5. Degrowth \\
\hline The role of EU strengthens. & $0.50[2.12]$ & $0.20[1.64]$ & $0.00[\text { N.A. }]^{a}$ & $2.33[0.82]$ & $0.71[1.50]$ \\
\hline The importing of energy becomes more difficult. & $1.00[0]$ & $0.40[1.14]$ & $2.00[\mathrm{~N} . \mathrm{A} .]^{\mathrm{a}}$ & $-1.50[1.22]$ & $0.00[1.00]$ \\
\hline The profitability in RE production increases. & $2.00[0.00]$ & $1.60[0.89]$ & $-1.00[\mathrm{~N} . \mathrm{A} .]^{\mathrm{a}}$ & $2.50[0.84]$ & $2.29[0.95]$ \\
\hline The consumption of RE becomes cheaper. & $0.00[2.83]$ & $1.00[0.71]$ & $2.00[\mathrm{~N} . \mathrm{A} .]^{\mathrm{a}}$ & $1.50[1.38]$ & $2.00[1.53]$ \\
\hline $\begin{array}{l}\text { Climate-friendly solutions increase, and climate } \\
\text { policy strengthens in the USA. }\end{array}$ & $-1.00[0.00]$ & $-0.40[1.52]$ & $2.00[\text { N.A. }]^{a}$ & 1.67 [1.03] & $1.57[0.53]$ \\
\hline $\begin{array}{l}\text { Climate-friendly solutions increase in big countries } \\
\text { like China and India. }\end{array}$ & $-0.50[0.71]$ & $0.80[1.10]$ & $3.00[\text { N.A. }]^{\mathrm{a}}$ & $2.17[0.41]$ & $2.14[0.38]$ \\
\hline International cooperation climate actions increase. & $1.00[2.83]$ & $1.40[0.55]$ & $3.00[\mathrm{~N} . \mathrm{A} .]^{\mathrm{a}}$ & $3.00[0.00]$ & $2.29[0.49]$ \\
\hline $\begin{array}{l}\text { NGOs' climate actions and power in society } \\
\text { increase. }\end{array}$ & $0.00[1.41]$ & $1.00[1.00]$ & $0.00[\text { N.A. }]^{a}$ & $2.67[0.52]$ & $2.29[0.76]$ \\
\hline Climate actions of individual citizens increase. & $2.00[1.41]$ & $1.20[0.45]$ & $3.00[\mathrm{~N} . \mathrm{A} .]^{a}$ & $2.50[0.55]$ & $2.14[0.69]$ \\
\hline Climate-friendly values strengthen in society. & $-1.00[0.00]$ & $1.40[0.89]$ & $3.00[\text { N.A. }]^{a}$ & $2.67[0.52]$ & $2.00[0.58]$ \\
\hline Citizens' own RE production is socially appreciated. & $-0.50[0.71]$ & $1.00[1.00]$ & $-1.00[\mathrm{~N} . \mathrm{A} .]^{\mathrm{a}}$ & $2.83[0.41]$ & $2.00[0.58]$ \\
\hline $\begin{array}{l}\text { Economic systems as a whole shift to climate- } \\
\text { friendliness. }\end{array}$ & $-2.50[0.71]$ & $1.20[0.84]$ & $3.00[\text { N.A. }]^{\mathrm{a}}$ & $1.67[1.21]$ & $2.00[1.00]$ \\
\hline $\begin{array}{l}\text { Economic growth is decelerated in a controlled } \\
\text { manner. }\end{array}$ & $-3.00[0.00]$ & $-1.40[1.14]$ & $-2.00[\text { [N.A. }]^{\mathrm{a}}$ & $-2.00[0.89]$ & $0.57[0.98]$ \\
\hline $\begin{array}{l}\text { Referendums about energy policy become more } \\
\text { popular. }\end{array}$ & $0.00[2.83]$ & $-1.60[0.55]$ & $2.00[\mathrm{~N} . \mathrm{A} .]^{\mathrm{a}}$ & $-0.50[1.05]$ & $1.14[0.69]$ \\
\hline $\begin{array}{l}\text { The power of citizens increases in Finnish energy } \\
\text { policy. }\end{array}$ & $-2.50[0.71]$ & $-0.60[0.55]$ & $-1.00[\text { N.A. }]^{\mathrm{a}}$ & $0.50[1.76]$ & $0.71[0.76]$ \\
\hline $\begin{array}{l}\text { Young people's possibilities of influencing } \\
\text { increase. }\end{array}$ & $-2.50[0.71]$ & $-0.40[1.14]$ & $-1.00[\text { [N.A. }]^{\mathrm{a}}$ & $1.83[0.75]$ & $1.14[0.69]$ \\
\hline
\end{tabular}

${ }^{a}$ Climate-friendly transformation scenario cluster contains only one response 
Table 3 The cluster centres (mean value [SD]) in each scenario regarding energy policy and its measures (those in bold are the ones that stand out between the clusters; scale from -3 to 3 )

\begin{tabular}{|c|c|c|c|c|c|}
\hline & 1. Business as usual & $\begin{array}{l}\text { 2. Energy } \\
\text { saving and } \\
\text { decarbonisation }\end{array}$ & $\begin{array}{l}\text { 3. Climate- } \\
\text { friendly } \\
\text { transformation }\end{array}$ & 4. Green growth & 5. Degrowth \\
\hline Energy policy will be stable and predictable. & $1.00[0]$ & $-1.00[0]$ & $-0.40[1.34]$ & $-2.00[1.00]$ & $1.00[0]$ \\
\hline Climate policy and targets will become stricter. & $1.67[0.58]$ & $2.00[0.71]$ & $2.20[0.45]$ & $2.33[0.58]$ & $2.33[0.58]$ \\
\hline $\begin{array}{l}\text { Best support for renewable decentralised produc- } \\
\text { tion is investment aid. }\end{array}$ & $-1.00[0]$ & $0.40[0.89]$ & $1.60[1.52]$ & $-1.00[2.65]$ & $2.00[1.00]$ \\
\hline $\begin{array}{l}\text { Best support for renewable decentralised produc- } \\
\text { tion is long-term production support. }\end{array}$ & $-0.33[1.15]$ & $0.60[1.14]$ & $1.20[1.30]$ & $-2.67[0.58]$ & $-2.00[1.00]$ \\
\hline $\begin{array}{l}\text { Best support for renewable decentralised produc- } \\
\text { tion is a combination of investment aid and } \\
\text { production support. }\end{array}$ & $\mathbf{1 . 3 3}[1.15]$ & $1.80[0.45]$ & $0.80[0.84]$ & $-2.00[1.00]$ & $-0.67[1.53]$ \\
\hline $\begin{array}{l}\text { Best support for renewable decentralised produc- } \\
\text { tion is tax allowances. }\end{array}$ & $1.33[0.58]$ & $2.75[0.50]$ & $1.40[1.14]$ & $0.67[1.53]$ & $2.00[0]$ \\
\hline $\begin{array}{l}\text { Energy subsidies should be neutral in terms of } \\
\text { scale and technology. }\end{array}$ & $1.00[1.73]$ & $1.00[2.74]$ & $2.00[0.71]$ & $-\mathbf{1 . 6 7}[2.31]$ & $1.67[2.31]$ \\
\hline $\begin{array}{l}\text { Basis for energy subsidies should be energy } \\
\text { efficiency. }\end{array}$ & $-1.00[0]$ & $1.60[1.67]$ & $2.40[0.55]$ & $0.67[2.31]$ & $1.00[1.73]$ \\
\hline $\begin{array}{l}\text { Basis for energy subsidies should be flexible pro- } \\
\text { duction capacity. }\end{array}$ & $0.00[1.00]$ & $2.33[0.58]$ & $1.20[0.84]$ & $1.33[2.08]$ & $1.67[0.58]$ \\
\hline $\begin{array}{l}\text { Basis for energy subsidies should be capability of } \\
\text { storing energy. }\end{array}$ & $-0.33[0.58]$ & $2.50[0.58]$ & $1.40[1.14]$ & $2.67[0.58]$ & $1.67[0.58]$ \\
\hline $\begin{array}{l}\text { Basis for energy subsidies should be the reduction } \\
\text { of GHGs. }\end{array}$ & $1.33[0.58]$ & $2.60[0.55]$ & $1.80[0.84]$ & $3.00[0]$ & $2.67[0.58]$ \\
\hline $\begin{array}{l}\text { No form of energy or fuel should receive perma- } \\
\text { nent subsidies. }\end{array}$ & 0.33 [1.15] & $2.60[0.55]$ & $1.80[1.30]$ & $2.50[0.71]$ & $3.00[0]$ \\
\hline
\end{tabular}

by wood energy, amplified by challenges in importing and the increase of wood chips as a residue of the forest industry as a prominent energy source. Innovations in the sharing economy and thermochemistry will enhance efficiency. Biogas has potential, but because of insufficient technology, poor cost-effectiveness, and low goals, it will not be fully utilised.

\section{Energy saving and decarbonisation}

The energy saving and decarbonisation scenario depicts a steady increase of the share of renewables. International cooperations' climate actions are increasing, and climatefriendly values are strengthening in society in general. Were it not for Finland's industrial structure and scarce population, the growth of renewables would be even more considerable. Throughout the 2020s, the profitability of RE technologies has increased, and the adoption of RE technologies has been rapid in local energy companies, enterprises, and households.

By 2030, the share of renewables will cover almost three-quarters of the total energy consumption, but the total consumption of energy will decrease in Finland, especially because of advances in energy efficiency. To enable the growth of the share of renewables, various sources of renewable energy will be promoted and utilised at the same time. Energy policy will be tailored throughout the field of different RE sources, and the objective will thus be to find the best combination of support policy measures for each of the sources. In addition, tax reductions will be used for producers, and administrative rules will be loose, supporting more freely the sale of energy to the grid from small-scale production sites. The guiding principle will be flexibility. Investments in pulp will enhance the use of wood energy, and industrial waste liquids and technological innovations will accelerate the use of ground-source heat pumps. Wind energy will be used to its full potential.

\section{Climate-friendly transformation}

The climate-friendly transformation scenario represents a world in which climate-friendliness is a strong driver in society, and the whole economic system has shifted in a climate-friendly direction. Economic growth has been decelerated in a controlled manner. Yet the decrease in consumption would be even sharper if it were not for the emergence of new consumption needs. Slow and steady progress is happening in RE energy, but the consumption of energy is decreasing somewhat more than in scenario 2 , mostly due to enhanced energy efficiency. 
The share of RE is about $60 \%$ of the total energy consumption. The RE capacity growth is supported by a technology-neutral support policy. The long-term production and energy-efficient solutions are especially supported. The climate-friendly values are strong throughout society. Globally leading countries, international corporations, and citizens all act in a manner that supports environmental well-being. National energy selfsufficiency is highlighted as the power export becomes more difficult. Citizens can vote in national elections, but it does not increase their power in energy issues; the leading role is played by international corporations and states. In this scenario, the profitability of RE production is moderate, and RE production also lacks appreciation at the grassroots level.

There are no dramatic changes in the share of renewable energy sources. Wood energy becomes more popular, mostly due to imported wood stuff. However, small-scale combustion of wood decreases because of urbanisation, lifestyle changes, and the growing amount of ground source heat and solar power. The urban structure becomes denser, leaving rural areas with fewer and fewer inhabitants. The share of renewables in combined heat and power production, as well as the share of biobased fuels increase in urban areas, but demand for distributed, small-scale energy systems in rural areas is low. Yet, the use of fossil fuels remains high. Nuclear power plants remain active and constitute the majority of nonrenewable energy.

\section{Green growth}

In the green growth scenario, green economic welfare prevails throughout society. Climate actions are the key focus of EU and global actors; all subsidies from fossilbased energy sources have been withdrawn, and an environmental protection tax has been implemented. Excellent profitability stimulates investment in RE. In addition, energy markets are well functioning, and investment in infrastructure enables flexible regional exports and imports.

Total energy consumption has increased due to the surge of economic growth, electrification, and lowering energy prices. Yet, it is harnessed to support economic growth and welfare in a climate-friendly way. RE capacity has grown rapidly and extensively through every source except wood energy. The sources that have been prioritised in energy policy have grown especially massively: biogas, ground source heat, geothermal heat, and solar power plug the gap of the decreased wood energy share. Heavy investment aids are also allocated to storage technologies, which enables balanced energy accessibility throughout the year in industry and housing. Overall, the rapid advance of RE technologies enhances the export of new innovations. Profitability has increased throughout the 2020s, and grassroots investment flourishes in RE small-scale technologies. This is highly appreciated in society. Younger people especially show an example in this, as the price of RE technologies is reduced.

The share of wood energy has decreased rapidly, because wood is considered too valuable to burn. Instead, higher level processing and wood as a construction material become increasingly popular. The share of water energy grows due to increased rainfall and novel innovations in pumped hydro.

\section{Degrowth}

The degrowth scenario places us in a world where the economic growth paradigm is abandoned, and economic activity has therefore declined through deliberative decisions in the EU and globally. Furthermore, new energyefficient technologies and an ageing population have reduced the need for energy in Finland. Degrowth has been people's choice and is a result of increased citizen power in society.

By 2030, the energy consumption has drastically decreased, and the share of renewables has grown. Short-term investment aids are used to increase climatefriendly RE technologies. A strict energy policy is utilised to control the decrease of GHG emissions, and burning wood is therefore avoided. In Finland, this means that forests are mainly used as carbon sinks, and commercial cuttings decrease. Wood is used for longer-lasting products that increase $\mathrm{CO}_{2}$ sequestration. Societal concern has radically accelerated technological development. As the need for energy has decreased drastically, the price of energy is cheap and affordable to anyone.

Pyrolysis and biocarbon as a soil improvement measure have considerably changed the energy use of forest biomass. This is considered to have a positive impact on forests as carbon sinks. The share of heat pump technologies increases steadily. A faster increase is imnpossible, because it might risk the high quality of technologies. Because of increased production efficiency and renewed equipment, the share of water energy has increased moderately.

\section{Discussion and conclusions}

In this article, we have used the Delphi method to analyse what kind of transition pathways energy experts see for renewable energy, and how the RE share can progress in total energy consumption. Experts also gave their views on the ongoing drivers and changes in the energy system's societal operating environment, and the role (triggering or hindering effect) of energy policy and its targeted measures in the transition to renewable energy futures. A common feature in each scenario is that RE shares are 
increasing. The level of decentralisation varies in the scenarios, but seems to advance, because wind, solar, and heat pumps are increasingly prominent. However, the role of small-scale producers and particularly citizens as voters (vs consumers) is not considered an especially important driver for change (see also [24, 25]).

The paper's key conclusions are the following. First, the experts' future views about the total consumption development up to 2030 varied considerably, ranging from 200 TWh to $420 \mathrm{TWh}$ (378 TWh in 2019). The extremities would entail drastic changes in the economic structure. The business as usual scenario seemed to follow quite exactly the national goals set for RE growth. Second, the experts saw strong societal trends for climate-friendliness, such as an increase of individual citizens' and international cooperations' climate actions, but their views diverged concerning the grassroots level, such as the power of citizens, especially young people, to influence societal goals. The age distribution of the panel might explain this. Third, the experts were convinced that climate and energy policy and its targets would become more ambitious. There was a consensus about some policy measures such as tax allowances, supporting flexibility in production capacity and gaining as much of a reduction of GHGs as possible. The experts had different views concerning whether the best support for $\mathrm{RE}$ production would be short-term investment aid or longterm production support to best trigger the change in the energy system.

The presented energy scenarios in this study follow Dator's [26, 27] framework of four alternative 'generic futures', sometimes also referred to as 'scenario archetypes' (e.g. [28-30]). According to Dator, the generic futures include (1) continued growth, where recent trends continue unquestioned; (2) collapse, where the system under study will collapse; (3) disciplined society, where society strongly controls development; and (4) transformation, where radical technological change will act as a game changer. In this paper, the first energy transition scenario, named business as usual, is close to the continued growth generic future. Degrowth is a clear collapse scenario, in which much less energy is used than at present. Energy saving and decarbonisation is compatible with the disciplined society future, in which the energy system is guided strongly in a favourable direction. The green growth scenario includes the most radical transformation from the current energy system to highly renewable energy in a green growth context. Another transformation scenario is 'climate-friendly transformation, which changes the path from the growth paradigm. This scenario is interesting from the contrasting point of view: welfare growth is gained from sources other than economic welfare.
Rotmans and Van Asselt [22] define scenarios as archetypical descriptions of alternative images of the future, created from mental maps or models that reflect different perspectives on past, present, and future developments. A scenario is thus an internally consistent story about the path from the present to the future. According to Van der Heijden [23], each of the scenarios must be plausible. That means that they must grow logically in a causeeffect way from the past and the present. Furthermore, they must be internally consistent. The events within a scenario must be related through cause-effect lines of argument, which cannot be flawed. Scenarios must also be relevant to the issues under scrutiny, provide useful and comprehensive idea generators, and test conditions against which the plans and strategies can be considered. Scenario planning is also more like a toolbox than a single method and can include various qualitative and quantitative data and methodological approaches (see also [31]). The presented scenarios in this article attempt to fulfil the criteria that are defined for scenario use (e.g. [22, 23]). In this paper, cluster analysis was used to build scenarios, which illustrate how varying sets of drivers in society, and are connected to energy policy scenarios. Such alternative scenario information can be used to interact and advise policymakers when designing climate and energy policy, but this research project was not directly part of Finnish energy and climate policymaking. The results in this manuscript are part of two broader research projects on decentralised renewable energy transition and governmental deliberative energy and climate foresight. The results of these projects have been and will be presented to decision-makers and stakeholders in the energy and climate sectors.

Foresight can be defined as action-oriented and participatory strategic intelligence focused on alternative futures. futures thinking can be used as a tool for inspiring actions and structures that address the global grand challenges [32]. Knowledge is produced interactively between multiple stakeholders with specific interests and various perspectives towards the topic under exploration [33]. Delphi-based results bring to the table the expert community perspectives on alternative paths, the potential challenges, and the needs for change in the energy system. Furthermore, such scenario work is presented as the views of experts concerning how society will respond to the changes required in the energy domain, and how the future energy system can combine information at various levels: from the societal to household level, from centralised to distributed energy systems, and from small-scale to large-scale technologies, etc. The variance between scenarios partly reflects large-scale landscapelevel trends such as the climate policy of other nations and the investment decisions of large corporations. 
Finnish energy sector development is therefore not only in the hands of domestic actors. The presented scenario worlds also systematically represent paths that can be seen as desirable, probable, and feasible. It can also bring into the discussion problematic or inconsistent future views. In the best case, the presented scenarios may prompt discussion and address measures concerning the strategy which the energy sector can adopt to achieve the ambitious national climate goals. One possibility to better operationalise the Delphi results could be a participatory, prospective value network approach proposed by Tuominen et al. [33]. It can widen the scope of system actors from linear value chain thinking to a transitionoriented network approach. Furthermore, it creates a transition arena for relevant stakeholders to create and share the same image of the future's holistic system in scrutiny, based on renewable energy.

Compared to those in most European nations, Finnish energy systems seem quite well prepared for the challenge of decarbonising their energy system. However, in the time frame of this research, the experts involved saw no dramatic increase in the role of new decentralised renewable energy solutions. Instead, much of the renewable energy production relied on the use of one resource, wood, and the success of a particular industrial field (the pulp and paper industry). The presented scenarios seek to challenge the current structure by asking if the current system can respond to future challenges, or if more diversity is needed. This leads to the ongoing discussion of system transformation changes: how to balance and utilise the best elements of centralised or decentralised systems, and the role citizens and other actors currently outside the energy regime should play.

\section{Acknowledgements}

We thank the interviewees and survey respondents for sharing their time and expertise. We also gratefully acknowledge the funding from the Academy of Finland (FutWend-project: grant numbers 297742 and 297747; DECENT project: grant numbers 325209 and 325207; and DEFORFO project: grant number 335648).

\section{Authors' contributions \\ Pasi Rikkonen is the corresponding author of the manuscript and has coordi- nated the writing process. Ville Lauttamäki and Pasi Rikkonen were responsible for the writing of the introduction chapter. Pasi Rikkonen and Vilja Varho were responsible for the writing of the methodological and data gathering process of the study. Pasi Rikkonen, Vilja Varho, and Petri Tapio have been equally responsible for the quantitative Delphi data analysis using cluster analysis as a statistical method. In addition, Marjukka Parkkinen has contributed to the scenario narratives using the open phrased qualitative answers from the Del- phi panellists. The discussion and conclusions chapter was first written by Pasi Rikkonen and Petri Tapio, but all authors contributed to the finalised version. The authors read and approved the final manuscript.}

\section{Authors' information}

Dr. Pasi Rikkonen received his doctorate from the Turku School of Economics. He has conducted numerous future-oriented studies and participatory scenario exercises within the fields of agriculture, food, and bioenergy. Dr. Ville Lauttamäki received his doctorate from the University of Turku. Lauttamäki studies futures of environment, energy, and security issues. Lately, his special area of interest has been sustainability transitions, especially regarding energy issues.

Marjukka Parkkinen, M.Sc. (Art and Design \& Futures Studies), works as a project expert at the Future Research Centre of the University of Turku. Parkkinen is preparing a doctoral thesis on the national foresight and strategy process and future concepts as part of decision-making.

Dr. Vilja Varho holds a doctorate in environmental science and policy from the University of Helsinki. She has studied various aspects of sustainability transitions, such as renewable energy and transport policies.

Petri Tapio is a Professor of Futures Research at UTU. He has published over a hundred publications on environmental futures studies in transport, energy, agri-food, and lake management and on futures research methodology.

\section{Funding}

We gratefully acknowledge funding from the Academy of Finland (FutWendproject: grant numbers 297742 and 297747; DECENT project: grant numbers 325209 and 325207; and DEFORFO project: grant number 335648).

\section{Availability of data and materials}

The Delphi process data was gathered by the researchers in the Natural Resource Institute Luke (organised by principal researcher Pasi Rikkonen) and stored in the databases of the participating research organisation Luke under password (including backup data in the organisation server). Luke was responsible for taking care of the registry containing identifying information of the participants and Privacy Notice of Processing Personal Data. The datasets generated during the Delphi process are available from the corresponding author when the project is over on a reasonable request. Data will be anonymised.

\section{Declaration}

Competing interests

The authors declare that they have no competing interests.

\section{Author details}

${ }^{1}$ Natural Resources Institute Finland (Luke), Mikkeli, Finland. ${ }^{2}$ Turku School of Economics, Finland Futures Research Centre, Turku University, Turku, Finland.

Received: 21 June 2021 Accepted: 9 October 2021

Published online: 27 October 2021

References

1. EU Commission. 2018. 2030 climate \& energy framework https://ec. europa.eu/clima/policies/strategies/2030_en (visited 12.2.2020)

2. IRENA (2019) Transforming the energy system - and holding the line on the rise of global temperatures. International Renewable Energy Agency, Abu Dhabi https://www.irena.org/publications/2019/Sep/Transformi ng-the-energy-system

3. Kainiemi L, Eloniemi S, Levänen J (2019) Transition towards a decentralised energy system: analyzing prospects for innovation facilitation and regime destabilisation in Finland. Technol Anal Strat Manag 31(9):10031015. https://doi.org/10.1080/09537325.2019.1582765

4. Finnish Government. 2019. Programme of Prime Minister Sanna Marin's Government 2019 https://valtioneuvosto.fi/en/rinne/government-progr amme/carbon-neutral-finland-that-protects-biodiversity

5. Tuominen A, Tapio P, Varho V, Järvi T, Banister D (2014) Pluralistic backcasting: integrating multiple visions with policy packages for transport climate policy. Futures. 60:41-58. https://doi.org/10.1016/j.futures.2014. 04.014

6. Bokrantz J, Skoogh A, Berlin C, Stahre J (2017) Maintenance in digitalised manufacturing: Delphi-based scenarios for 2030. Int J Prod Econ 191(2017):154-169. https://doi.org/10.1016/j.ijpe.2017.06.010

7. Fritschy C, Spinler S (2019) The impact of autonomous trucks on business models in the automotive and logistics industry-a Delphi-based scenario study. Technol Forecasting Soc Change 148(2019):119736. https://doi. org/10.1016/j.techfore.2019.119736

8. Jiang R, Kleer R, Piller FT (2017) Predicting the future of additive manufacturing: a Delphi study on economic and societal implications of 3D 
printing for 2030. Technol Forecasting Soc Change 117(2017):84-97. https://doi.org/10.1016/j.techfore.2017.01.006

9. Rikkonen P, Tapio P (2009) Future prospects of alternative agro-based bioenergy use in Finland - constructing scenarios with quantitative and qualitative Delphi data. Technol Forecasting Soc Change 76(7):978-990. https://doi.org/10.1016/j.techfore.2008.12.001

10. Tapio P, Rintamäki H, Rikkonen P, Ruotsalainen J (2017) Pump, boiler, cell or turbine? Six mixed scenarios of energy futures in farms. Futures 88:30-42. https://doi.org/10.1016/j.futures.2017.03.003

11. Feilzer MY (2009) Doing mixed methods research pragmatically: implications for the rediscovery of pragmatixm as a research paradigm. J Mixed Methods Res 4(1):6-16. https://doi.org/10.1177/1558689809349691

12. Lauttamäki, V. 2018. Geoenergia kiinteistöjen lämmitysratkaisujen markkinoilla Suomessa energiakriisien ajoista 2030-luvulle. Turun yliopiston julkaisuja - Annales Universitatis Turkuensis, Sarja - ser. E, Osa - tom. 29. Oeconomica. Turku 2018. Väitöskirja. [eng. Ground-source heat on facilities' heating market in Finland from the times of energy crisis in the 1970s until 2030. Doctoral dissertation] http://urn.fi/URN:ISBN: 978-951-29-7234-0

13. Lauttamäki V, Hyysalo S (2019) Empirical application of the multi-level perspective: tracing the history of ground-source heat pumps systems in Finland. Sustain: Sci Pract Policy 15(1):82-103. https://doi.org/10.1080/ 15487733.2019.1678372

14. Winquist E, Rikkonen P, Pyysiäinen J, Varho V (2019) Is biogas an energy or a sustainability product? - business opportunities in the Finnish biogas branch. J Clean Prod 233:1344-1354. https://doi.org/10.1016/j.jclepro. 2019.06.181

15. Winquist E, Van Galen M, Zielonka S, Rikkonen P, Oudendag D, Zhou L, Greijdanus A (2021) Expert views on the future development of biogas business branch in Germany, The Netherlands, and Finland until 2030. Sustainability 13(3):20. https://doi.org/10.3390/su13031148

16. Statistics Finland. 2019. Energy 2019 table service. 2. Consumption of some fuels and energy source 2.8 renewable energy https://pxhop ea2.stat.fi/sahkoiset_julkaisut/energia2019/html/engl0001.htm (visited 15.6.2020)

17. Vainio A, Varho V, Tapio P, Pulkka A, Paloniemi R (2019) Citizens'images of a sustainable energy transition. Energy 183:606-616. https://doi.org/10. 1016/j.energy.2019.06.134

18. Everitt BS, Landau S, Leese M (2001) Cluster analysis, 4th edn. Arnold, London

19. Distler O, Behrens F, Pittrow D, Huscher D, Denton CP, Foeldvari I, Humbert M, Matucci-Cerinic M, Nash P, Opitz CF, Rubin LJ, Seibold JR, Furst DE (2008) Defining appropriate outcome measures in pulmonary arterial hypertension related to systemic sclerosis: a Delphi consensus study with cluster analysis. Arthritis Care Res 59(6):867-875. https://doi.org/10.1002/ art.23718

20. Tapio P (2003) Disaggregative policy Delphi. Using cluster analysis as a tool for systematic scenario formation. Technol Forecasting Soc Change 70(1):83-101. https://doi.org/10.1016/S0040-1625(01)00177-9

21. Varho V, Tapio P (2005) Wind power in Finland up to the year 2025 -'soft' scenarios based on expert views. Energy Policy 33:1930-1947. https://doi. org/10.1016/j.enpol.2004.03.006

22. Amer M, Daim T U, Jetter A (2013) A review of scenario planning. Futures 46:23-40. https://doi.org/10.1016/j.futures.2012.10.003
23. Van der Heijden K (1996) Scenarios - the art of strategic conversation. Wiley, Chichester, p 305

24. Ruggiero S, Varho V, Rikkonen P (2015) Transition to distributed energy generation in Finland: prospects and barriers. Energy Policy 86:433-443

25. Varho V, Rikkonen P, Rasi S (2016) Futures of distributed small-scale energy in Finland - a Delphi study of the opportunities and obstacles up to 2025. Technol Forecasting Soc Change 104:30-37. https://doi.org/10. 1016/j.techfore.2015.12.001

26. Dator J (1998) Introduction. The future lies behind! Thirty years of teaching futures studies. Am Behav Sci 42(3):298-319

27. Dator J (2009) Alternative futures at the Manoa School. J Fut Stud 14(2):1-18

28. Curry A, SchultzW (2009) Roads less travelled: different methods, different futures. J Fut Stud 13(4):35-60

29. Fergnani A (2019) Scenario archetypes of the futures of capitalism: the conflict between the psychological attachment to capitalism and the prospect of its dissolution. Futures 105:1-16

30. Hunt DVL, Lombardi DR, Atkinson S, Barber ARG, Barnes M, Boyko CT, Brown J, Bryson J, Butler D, Caputo S, Caserio M, Coles R, Cooper RFD, Farmani R, Gaterell M, Hale J, Hales C, Hewitt CN, Jankovic L, Jefferson I, Leach J, MacKenzie AR, Memon FA, Sadler JP, Weingaertner C, Whyatt JD, Rogers CDF (2012) Scenario archetypes: converging rather than diverging themes. Sustainability 4(4):740-772

31. Fauré E, Arushanyan Y, Ekener E, Miliutenko S, Finnveden G (2017) Methods for assessing future scenarios from a sustainability perspective. Eur J Fut Res 5(17). https://doi.org/10.1007/s40309-017-0121-9

32. De Smedt P, Borch K, Fuller T (2013) Future scenarios to inspire innovation. Technol Forecasting Soc Change 80(3):432-443. https://doi.org/10. 1016/j.techfore.2012.10.006

33. Tuominen A, Wessberg N, Leinonen A (2015) Participatory and prospective value network analysis: supporting transition towards biofuels in Finnish road transport. Eur J Fut Res 3(6). https://doi.org/10.1007/ s40309-015-0064-y

34. Eurostat. 2020. Share of renewable energy in gross final energy consumption https://ec.europa.eu/eurostat/data/database (visited 12.5.2020)

35. Statistics Finland (2020) Energy supply and consumption [e-publication]. Statistics Finland, Helsinki [referred: 24.3.2021]. Access method: http:// www.stat.fi/til/ehk/2019/ehk_2019_2020-12-21_tie_001_en.html

36. Varho V, Tapio $P$ (2013) Combining the qualitative and quantitative with the Q2 scenario technique - The case of transport and climate. Technol Forecasting Soc Change 80(4):611-630. https://doi.org/10.1016/j.techf ore.2012.09.004

\section{Publisher's Note}

Springer Nature remains neutral with regard to jurisdictional claims in published maps and institutional affiliations.

\section{Submit your manuscript to a SpringerOpen ${ }^{\circ}$ journal and benefit from:}

- Convenient online submission

- Rigorous peer review

- Open access: articles freely available online

- High visibility within the field

- Retaining the copyright to your article

Submit your next manuscript at $\boldsymbol{\nabla}$ springeropen.com 